\title{
RESEARCH AND PATENTING IN COVID TIMES
}

Dear Reader,

Government of India is currently negotiating a limited trade deal with USA which is likely to be signed after the US elections. Although, the current negotiations do not cover the Intellectual Properties (IP) or Pharmaceuticals, a limited deal if concluded successfully is expected to be followed by a full Trade Deal (FTA), which will include IP and Pharmaceuticals too.

In spite of all the negative (or positive?) consequences of COVID-19, the Sars2CoV virus has provided humanity with a great learning experience. Repurposing of known drugs, bio-natural products, biologicals and vaccines

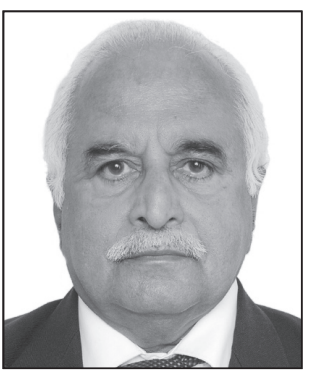
such as TB, Leprosy, BCG have all been undertaken in the desperate search for prophylactic, therapeutic as well as preventive options. However it is interesting to note and appreciate that except for pre-existing patent rights (ex:-Remdesivir), there have hardly been any emphases on protecting the Covid remedies through patenting.

Balancing of rights and obligations have always been an integral aspect of Patent Laws ever since the Paris Convention was adopted in 1883. The TRIPs (Trade Related Aspects of Intellectual Property Rights) has incorporated and adopted all the provisions of Paris conventions as per Article 2 of TRIPs. Further, under the Objective and Principle of TRIPs, it is explicitly stated in Article 7 and 8, which respectively refer to "transfer and dissemination of technology to the mutual advantage of producers and users of technological knowledge in a manner conducive to social and economic welfare, and to a balance of rights and obligations" and also "Members may adopt measures necessary to protect public health and nutrition and to promote public interest....". As such, member countries like India do provide such balancing provisions in the National Patent laws such as the Patents Act 1970 of India. However, in developed countries such as USA, the patent provisions are constantly evolving based on juridical judgments from the US Courts. The US Patent law, 35 US code is very brief unlike Patents Act, 1970 of India, where the balance has moved substantially in favor of the Inventors and the Patent owner. Consequently, USA has been extensively critical of Indian Patent provisions leading to USTR (United Sates Trade Representative) issuing Super 301 Trade notifications over the last few years. India's response has been more defensive, though our Trade negotiators have successfully explained our position on the balance of rights and obligations. However, it is time now, especially in view of the global pandemic, for us to convince the developed countries like USA to provide needful emphasis on healthcare protection in preference to patent protection.

Indian patent provisions as per Patents Act, 1970 has been challenging for Indian Inventors and their Patent Agents/Attorneys. India's unique permission under Sec 3"What are not inventions" "What are not patentable" (Sec 3(d) for example) has been a real hurdle unlike USA, over and above the tough "Obviousness" criteria adopted by the Indian Examiners.

Pricing of pharmaceuticals has been tightly controlled under NPPA (National Pharmaceutical Pricing Authority) except for patented molecules, most of which are either wholly imported or exclusively licensed with terms and conditions. As such, Indian Patents and healthcare providers have been under an advantage vis-à-vis affordable access and generic options widely being available without market monopolies.

Indian Pharmaceutical researchers and manufacturers in the field of natural products have been facing the additional challenge from the Biodiversity Act, 2002 and the Rules 2004, which had been prematurely promulgated ahead of the Nagoya Protocol and which had been very tardily drafted. To add insult to injury, the procedural provisions have all along been harsh and 
narrowly interpreted. While world over (ex-China, Japan, Asian countries) the pharmaceutical industry has been looking at integrating options through products of natural origin, Indian researchers have been extremely stifled in their options for herbal remedies due to the NBA (National Biodiversity Authority). A simple example is cited to explain the dilemma. A distinguished academic pharma research professor came up with a novel invention of an antifertility agent and formulation from the extract of the seeds of Annona Squamosa (Seetaphal). Not only did the NBA demand 5\% royalty on all income generated from the invention, but the Biodiversity Authorities insisted on the inventor disclosing the original origin of the seed geographically for benefit sharing. Paradoxical indeed.

Coming back to the subject of R\&D in COVID times, the only option should be to invent or reinvent through repurposing effective remedies and cures for the virus infection and treatment thereof. Even the Remdesivir patent had to be saved from Compulsory License by liberal Voluntary Licensing by Gilead. It is a common man's concern. "Will the vaccines for COVID be patented?" "No way", let us comfort ourselves, atleast not in India. Fortunately, India is in forefront of Vaccine development and manufacturing at extremely affordable pricing.

In the meantime, planning for growth by the pharma industry needs an integrated approach. Leading Indian manufacturers like Zydus Cadila and Cipla have grown exemplarily through an integrating approach by adopting organic as well as inorganic routes. While APIs and building blocks will continue to grow and receive much deserved attention, the formulation industry is bound to expand horizontally and vertically in technology options keeping the consumers benefit in mind. For example, Cipla who started aerosol business in 1976 is becoming a global leader through acquisition of respiratory device manufacturing companies both in India as well as overseas. The announcement of a Rs. 1000 crore acquisition of a leading US inhaler manufacturing company is a crowning glory for an Indian Pharmaceutical giant. After reaching a critical mass, the Indian Pharmaceutical manufacturers need to look at strengthening the operations by adopting an integrated approach through development or acquisition of technologies. Emphasis in future will be on "Innovation" and "Novel" technologies and healthcare solutions.

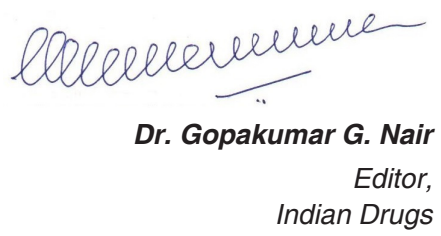

https://doi.org/10.53879/id.57.08.p0005

Indian Drugs

\section{About The Editor}

Dr. Gopakumar G. Nair is a Ph.D in Organic Chemistry (1966) from National Chemical Laboratory, Pune (Pune University). He was a Post-Doctoral fellow at IIT Bombay, Powai (1967) before joining the Pharma Industry. He was Director of Bombay Drug House P. Ltd., later Chairman of BDH Industries Ltd. as well as CMD of Bombay Drugs \& Pharma Ltd., which was merged with Strides Arcolab Ltd. in 2001. Dr. Nair served IDMA as office bearer for many years from 1972 onwards and was Chairman of various Committees for nearly 4 decades. He was the President of IDMA in 1999/2000. Currently, Dr. Nair is the Chairman of the IPR Committee in IDMA.

Having moved into the Intellectual Property field, he was the Dean of IIPS (Institute of Intellectual Property Studies) at Hyderabad in 2001/2002. Later, he set up his own boutique IP firm, Gopakumar Nair Associates, as well as Gnanlex Hermeneutics Pvt. Ltd., having done his L. L. B. from Mumbai University. He is also CEO of Patent Gurukul and President of Bharat Education Society, Kurla, Mumbai, managing many educational institutions in and around Mumbai.

If you would like to comment on the editorial please write to us at publications@idmaindia.com 